\title{
PAISAGENS SENSÍVEIS, POÉTICAS DO IMAGINÁRIO E MEMÓRIAS COMPARTILHADAS PELOS ANTIGOS MORADORES DA ILHA DE COTIJUBA, BELÉM, PARÁ
}

\author{
Carla Melo Vasconcelos (D) $ه$
}

Flávio Leonel Abreu da Silveira (D) Universidade Federal do Pará I Belém -PA - Brasil 
Neste trabalho, apresentamos reflexões acerca de um estudo sobre o universo fantástico que envolve as paisagens, imaginários e memórias dos antigos moradores da ilha de Cotijuba, Pará. Apresentamos dados de duas viagens a campo, onde optamos por destacar três narradores em específico: Dona Zilda, da comunidade do Farol, Seu Dimas, da comunidade da Pedra Branca, e Seu Jorge, da comunidade do Vai-Quem-Quer, todas localizadas de norte a sul da ínsula. Aqui, expomos alguns apontamentos suscitados pelo encontro com os narradores e a narradora, de forma a pensarmos as suas experiências a partir do diálogo com uma bibliografia específica. A vivência com tais narradores auxiliou-nos a adentrar no universo de seus cotidianos e, mais diretamente, em suas casas e quintais, desde onde os saberes e memórias sobre a ínsula emergiram, entrelaçando imaginários e ambientes mediante narrativas fantásticas, poéticas orais e paisagens sensíveis, envolvendo, principalmente, o lugar das histórias contadas e recontadas sobre seres fantásticos e almas penadas, que pretendemos abordar ao longo da discussão presente neste artigo.

Palavras-chave: paisagens sensíveis; imaginário; memórias

\section{SENSITIVE, POETIC LANDSCAPES OF THE IMAGINARY AND MEMORIES SHARED BY THE FORMER RESIDENTS OF THE ISLAND OF COTIJUBA, BELÉ, PARÁ}

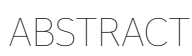

On this paper we aim to present some reflections about the fantastic universe which involves the landscapes, imaginaries and the ancient inhabitants' memories about Cotijuba Island (PA). We highlight three specific narrators: Zilda, from the Farol community, Dimas, from the Pedra Branca community, and Jorge, from the Vai-Quem-Quer community. Here, we introduce the narrators' points of view in order to think about their experiences through the dialogue with a specific bibliography. The experience of these narrators helped us to enter into the universe of their daily lives, more specifically inside their homes and backyards, since it's where the knowledge and memories about the island emerged, interlacing imaginary and environments through fantastic narratives, oral poetics and delightful landscapes, involving specially the place of the stories about fantastic beings and abandoned souls, which we intend to approach throughout this article.

Keywords: sensitive landscapes; imaginary; memories

\section{PAISAJES SENSITIVOS Y POÉTICOS DEL IMAGINARIO Y RECUERDOS COMPARTIDOS POR LOS ANTIGUOS HABITANTES DE LA ISLA DE COTIJUBA, BELÉM, PARÁ}

En este trabajo presentamos reflexiones acerca de un estudio sobre el universo fantástico que envuelve los paisajes, imaginarios y memorias de los antiguos habitantes de la isla de Cotijuba (PA). Presentamos datos de dos salidas de campo, donde optamos por destacar tres narradores específicos: Doña Zilda, de la comunidad Farol, Dimas, de la comunidad Pedra Branca, y Jorge, de la comunidad Vai-QuemQuer, todas ubicadas en de norte a sur de la ínsula. Exponemos algunos apuntes suscitados por el encuentro con los narradores y la narradora para pensar sus experiencias a partir del diálogo con una bibliografía específica. La experiencia con tales narradores nos ayudó a adentrarnos en el universo de su vida cotidiana y, más directamente en sus casas y patios, desde donde los saberes y memorias sobre la ínsula emergieron entrelazando imaginarios y ambientes mediante narrativas fantásticas, poéticas orales y paisajes sensibles, envolviendo, principalmente, , el lugar de las historias contadas y recontadas sobre seres fantásticos y almas penadas, de las que pretendemos abordar en la discusión presente en este artículo.

Palabras clave: paisajes sensibles; imaginário; memorias 


\section{0 CAMINHO DAS ALMAS: MEMÓRIAS COMPARTILHADAS DO LUGAR}

Este artigo resulta de um estudo poéticoetnográfico realizado em torno de narrativas das memórias dos antigos moradores da ilha de Cotijuba ${ }^{1}$, localizada na porção da Belém insular. Assim, o arquipélago ${ }^{2}$ estabelece parcela significativa com a cidade de Belém, Pará, mais especificamente quanto às relações sensíveis que instituíram com os seus lugares de pertencimento e às formas de praticá-las ao longo do tempo (Simmel 1983; Certeau 1994).

Como ponto de chegada, levamos em conta a perspectiva simbólica de um espaço insular. A ilha de Cotijuba não é exatamente o objeto da pesquisa, mas o lugar dele. O objeto da pesquisa visa perceber as relações estabelecidas entre as narrativas orais contadas pelas memórias dos narradores e narradora antigos da ilha de Cotijuba e suas vivências, e, assim, perceber as memórias compartilhadas que delas afloram. Quando enfatizamos o lugar da pesquisa, estamos nos referindo ao lugar que comporta significados, afetos e desejos que tecem esse espaço geográfico insular.

Nesse mergulho, relatamos alguns momentos das experiências de pesquisa de campo durante a travessia de Icoaraci ${ }^{3}$ até a ilha. Entre idas e vindas, observamos as paisagens cotidianas dos ribeirinhos e suas relações com a ilha. Viagens realizadas para a tessitura da pesquisa da dissertação de mestrado da primeira autora, do Programa de PósGraduação em Linguagens e Saberes da Amazônia, da Universidade Federal do Pará, em 2015, com a orientação do segundo autor deste artigo.

Desde criança, a primeira autora tem conhecimento de muitas histórias sobre a ilha de Cotijuba, que lhes aguçavam a imaginação. Sua infância foi povoada de muitas histórias trazidas da ilha por avôs de seus primos, os quais residiam na ilha. Segundo a primeira autora: "É só cerrar as pálpebras e rememoro muitas vozes”.

Neste estudo, utilizamos o conceito de "memória compartilhada", de acordo com Paul

1 Neste sentido, seguimos as indicações de Ecléa Bosi (1995:60), que afirma o seguinte sobre "[a] situação do velho, do homem que já viveu sua vida”: "Ao lembrar o passado ele não está descansando, por um instante, das lides cotidianas, não está se entregando fugitivamente às delícias do sonho: ele está se ocupando consciente e atentamente do próprio passado, da substância mesmo da sua vida”.

2 A ilha de Cotijuba está localizada, geograficamente, entre a ilha do Marajó, ao sul, as ilhas de Jutuba e Paquetá, ao norte. Assim, está situada em meio às baías do Marajó, a qual banha sua costa, e do Guajará, localizada à sua entrada.

3 Distrito que fica geograficamente situado a $15 \mathrm{~km}$, aproximadamente, do centro de Belém, em uma área considerada periférica, como muitos bairros da capital paraense. Apresenta o mesmo jeito de ver, pensar e sentir a vida na área urbana e vivencia cotidianamente as transformações do tempo e do espaço, bem como o desalojamento do sistema social, fazendo com que ocorra a extração das relações sociais (Figueiredo \& Tavares 2006). 
Ricoeur (2007), buscando compreender aspectos das narrativas que emanam do esforço de lembrar por parte dos moradores antigos da ilha, mais diretamente do ato criativo de rememorarem as suas experiências e trajetórias pessoais junto ao espaço em que residem e, a partir daí, de tecerem as suas narrativas.

Portanto é a partir das memórias suscitadas pelos narradores e das imagens evocadas por elas que o embate entre lembranças e esquecimentos se deflagra como uma forma sensível para lidar com o imaginário relacionado a uma cultura do terror, que vibra nas paisagens (Sansot, 1983; Durand, 1989; Taussig, 1993; Simmel, 1983, e, a partir daí, pelos quais compartilham suas narrativas com as pessoas nas diversas comunidades presentes na ilha. Neste sentido, essa experiência envolve uma memória tecida pela experiência convivial entre as comunidades narrativas na ínsula.

Trata-se de levar em consideração o constante "trabalho" de lapidar a performance sobre as memórias exercidas pelos narradores - no sentido de que (re)contam histórias locais a um público atento e, assim, fornecem formas poéticas renovadas, reconfiguradas constantemente no ato de narrar -, que pode ser expresso por intermédio do "fenômeno de transmissão de memória de avós para netos, de pais para filhos, no sentindo de uma memória transgeracional” (Ricoeur 2007:513).
No que tange as agências cotidianas, aos residentes mais antigos da ilha adquirem um lugar de relevância na transmissão e reinterpretação das experiências cotidianas de interação das comunidades com as paisagens da ilha ao longo do tempo.

Nessa perspectiva, as memórias transgeracionais se desdobram em formas sutis de ligação entre as pessoas, envolvendo o ato de se pensar e se sentir como uma comunidade narrativa constituída por gerações ascendentes e descendentes, que se ordenam segundo as experiências em comum, que aproximam as pessoas pertencentes a determinado lugar, neste caso, através das lembranças dos moradores da zona insular da cidade de Belém.

A partir das tensões entre o presente vivido e o passado rememorado, essas memórias compartilhadas da/na ilha de Cotijuba estão compostas, não raro, por narrativas de caráter mítico e encontram nas dinâmicas das imagens presentes nas paisagens uma forma de fazer durar os gestos e saberes que evocam o tempo dos antigos moradores da ilha, narrados no presente aos mais jovens.

$\mathrm{O}$ ato de contar e de ouvir histórias cotidianamente, no nosso ponto de vista, se constitui numa forma altamente elaborada de interação performático-criativa que indica maneiras de jogar o social em determinado 
contexto e, a partir daí, de dinamizar um acervo vivo de narrativas que circulam entre as gerações, unindo contadores e ouvintes através de laços afetivos, de caráter sensível, em torno de expressões locais de sociabilidade.

A movência das narrativas faz com que a figura do narrador de histórias pareça, a partir do fluxo de suas memórias, uma espécie de grande arquivo vivo de experiências vivenciais e imagéticas ligadas aos lugares relacionados aos saberes e fazeres de um grupo social que, considerando o narrador, revela os acontecimentos que marcaram as memórias da ilha de Cotijuba e se entranharam nesses lugares.

É, portanto, através de uma narrativa, ou, ainda, da narração das memórias de outrora, que se processa o ato paciencioso da escuta, que o ouvinte se educa na experiência de ouvir e de figurar numa paisagem sonora. Assim, antes de nos apropriarmos de nossa capacidade narrativa (de contarmos histórias), ouvimos histórias - pelo menos, no interior da Amazônia se ouve ${ }^{4}$. A pluralidade de narrativas sobre a ilha de Cotijuba se alinha como força produtora em devir, as quais são capazes de engendrar uma performance poética-criativa da paisagem que dinamiza o espaço-tempo da ilha.

Nestes termos, se as memórias participam, e são constitutivas, das experiências dos sujeitos no mundo, elas o são a partir dos vínculos simbólicos e afetivos que estabeleceram com uma comunidade de destino na duração de uma vida, portanto, são eminentemente sociais, o que, de acordo com Halbwachs (2003), nos levaria a distinguir dois tipos de memórias: uma com caráter mais interior e outra com caráter exterior (Halbwachs 2003:93), mas em conexão com o devir no espaço-tempo de uma vida entrelaçada a outras.

Existe, assim, uma memória autobiográfica e outra memória histórica (Bosi, 1994). E, assim, a primeira se apoiaria na segunda, e vice-versa, pois toda história da nossa vida faz parte de uma história mais geral, que é forjada por indivíduos tensionalmente. Nestes termos, a memória coletiva (Halbwachs 2003) seria uma dimensão mais pontual e cotidiana, reforçada a cada vez que se reconta uma história vivida, que circula de boca em boca e constitui, junto com outros elementos, a aura de uma paisagem, suas fulgurações sensíveis (Eckert \& Rocha 2000).

Ora, como observa Ricoeur (2007:164), “nós pertencemos a grupos sociais portadores de uma memória, memória essa que preside as relações

4 Este parágrafo tem inspiração em vários autores. Neste sentido, operamos mais livremente com o arcabouço teóricoconceitual referenciado na bibliografia final deste artigo. 
intersubjetivas e que é derivada das mesmas". Para o autor, a memória é sempre relacional, pois, visando unicamente à interioridade, torna-se objeto de dúvidas e de suspeitas. Neste sentido, essa fluidez das memórias vibra numa rítmica instável, como as ondas de um oceano de ideias e imagens que falam a Bachelard (1997) das descontinuidades assentadas numa dinâmica do tempo, construindo memórias coletivas através do encontro com o outro, no esforço de lembrar e de lidar com as dinâmicas do esquecimento. Para nós, os acontecimentos do passado, associados à (re) configuração de imagens aliadas à permanência do presente, geram complexas formas de interação entre os indivíduos, e deles com as paisagens locais, que perpassam as experiências cotidianas. É por isso que, em nosso estudo, tomamos as entrevistas com os narradores da pesquisa como uma forma de seguirmos em direção ao "tempo vivido pensado" (Eckert 2009) e selecionamos um repertório compartilhado de histórias provenientes da "comunidade narrativa" (Langdon 1999) da ilha de Cotijuba, tecido por intermédio das representações poético-imagéticas das narrativas fantásticas ${ }^{5}$, que remetem a um repertório coletivo de contos dessas comunidades.

Partimos do princípio de que as imagens vibram na Amazônia e parecem esconder recantos de ilhas e de arquipélagos suntuosos, repletos de mistérios e de possibilidades ligadas às "entidades culturais imaginárias" (Lezama Lima 2001) que emanam das histórias contadas pelos velhos moradores locais acerca do cotidiano das comunidades narrativas presentes nas ilhas do entorno da cidade de Belém, pouco conhecidas porque fazem parte desses lugares considerados distantes e ermos no contexto metropolitano. Parece-nos, assim, que as narrativas orais constituintes das memórias - como formas de autoconstrução subjetiva de indivíduos e grupos com identidades coletivas representam um esforço para nutrir as identidades dessas comunidades insulares com uma vitalidade própria e, portanto, de fortalecerem os vínculos simbólico-práticos com os lugares de pertença.

Na ilha, percebemos que há diversos contextos onde se entranham as memórias dos lugares, como o são as praias e os igarapés, as ruínas do educandário ou as roças abandonadas, certas árvores e rochas, recantos da mata ou trilhas sinuosas que recortam cenários, desenhando labirintos de lugares praticados (Certeau 1994) em Cotijuba, que reverberam naqueles das memórias.

Por outro lado, não se tratam de memórias referidas a qualquer lugar, mas de lembranças tensionadas a esquecimentos relativos às vicissitudes da vida numa ilha, de sentimentos mais ou menos expressos de uma insularidade ligada ao cotidiano e ao prosaico, mas, ao mesmo tempo, ao fantástico e ao terrificante (Silveira

5 Sobre narrativas/paisagens fantásticas, ver a tese de doutorado de Silveira (2004). 
2004; Rocha \& Eckert 2005). Nestes termos, as ilhas, pelo fato de serem territórios rodeados por águas mais ou menos agitadas, mas sempre misteriosas, nutrem o imaginário sobre a insularidade enquanto locus do distante, do exótico, quiçá da morada de seres estranhos. Há uma expressiva produção contemporânea que nos instiga a percorrer por tais caminhos, e esperamos conseguir esboçar as transformações das paisagens da insula, buscando cotejá-las nas narrativas de alguns moradores mais antigos, especificamente quando evocam imagens de uma paisagem em devir. Elas aparecem nas narrativas das pessoas mediante uma multiplicidade de discursos que afloram também no exotismo como atrativo turístico, enfatizando-se no contexto amazônico a rica biodiversidade local e os "mistérios" que as cercam.

Para tanto, o imaginário sobre o lugar é revestido pelas narrativas acerca das vivências dos narradores na e da ilha de Cotijuba, com ênfase em construções simbólicas que a designam como um "paraíso próximo" da imagem de refúgio, como um abrigo com características singulares que guardam narrativas de vários gêneros, sendo, ainda, percebida pelos visitantes como ilha-praia sem tantas ações predatórias humanas.

No imaginário dos que visitam Cotijuba, as ilhas continuam suscitando fascinação. Muitas pessoas do continente (ou de outras regiões) a consideram como a própria imagem do isolamento, do refúgio, como contraponto à vida urbanizada. Quando elementos do mundo industrializado penetram nesses ambientes, supõe-se que a vida dos insulares nunca mais será a mesma, porque já não resta a aura de paraíso intocado.

Narrativas orais sobre ilhas foram suscitando textos relacionados com os espaços insulares que estão associados a diferentes gêneros literários, desde tempos mais remotos. Orlando Ribeiro (1960:19) refere-se ao fato de que "a lenda das Ilhas Afortunadas criou-se na Antiguidade, quando a imaginação dos homens procurava, num lugar perdido e distante, um mundo melhor que este vivia”.

É com esta perspectiva romantizada
sobre os espaços insulares, que
Thomas More publica pela primeira
vez em 1516 a obra "Utopia", a qual
representa uma ilha (imaginária)
habitada por uma sociedade perfeita.
Nesse mesmo século, o português Luís
de Camões inclui nos "Lusíadas" o mito
da "Ilha dos Amores". Reforçando um
imaginário idílico sobre os espaços
insulares (Espínola \& Cravidão 2014:45
apud Ribeiro 1960:19).

Nesta complexa construção imaginária europeia, as ilhas são como que um "espaço-solução" para os problemas socioeconômicos cotidianos das sociedades (continentais) de épocas distintas. Assim, é possível perceber as influências visíveis das ilhas enquanto cenários para as narrativas literárias ficcionais. O imaginário humano antigo e contemporâneo está repleto de imagens referentes 
às ilhas que se manifestam sob a forma de mitos, de símbolos, enfim, de simbólicas imagens plurais.

Antônio Carlos Diegues (1998) apresenta, em

"Ilhas e mares: simbolismo e imaginário", uma apreciação mais focada nas imagens insulares, bem como nos diversos significados que as ilhas assumiram na cultura ocidental desde a Antiguidade Clássica até a contemporaneidade. Segundo o autor:

O mundo insular é um símbolo polissêmico, com vários conteúdos $\mathrm{e}$ significados que variam de acordo com a História e as sociedades.

Mundo em miniatura, centro espiritual primordial, imagem completa e perfeita do cosmos, inferno e paraíso, liberdade e prisão, refúgio e útero materno, eis alguns significados que o homem atribuiu a esse microcosmo (Diegues 1998:13).

Sérgio Buarque de Holanda, em "Visão do paraíso", indica que "o paraíso fora do espaço continental, também descrito na Antiguidade, se converte como o fundamento para o romantismo insular que invadiu a Europa a partir dos descobrimentos marítimos modernos" (Holanda 1996:152). O autor recorre aos relatos de navegantes e viajantes, às cartas cartográficas da época, bem como às histórias recontadas por quem não viajou, mas escutou sobre as aventuras além-mar e as recontou, acrescentando suas expectativas e medos, promovendo, assim, a resignificação de vários lugares míticos insulares ao longo do tempo.

\section{É importante acentuar que as narrativas} dos ilhéus, no caso de Cotijuba, assentam-se no cotidiano da ilha baseado na lida com seus saberes e seus fazeres num território existencial, pois são eles tanto personagens quanto narradores das histórias que contam para si e para outros; enquanto os visitantes da ilha marcam seus discursos sobre ela ajustados às paisagens sui generis, compreendidas enquanto áreas de lazer e de descanso, como espaço de fuga da urbanidade da metrópole - possuem um outro olhar, carregado de um passado de compartilhamento restrito, ancorado em "memórias subterrâneas ${ }^{6}$ ou marginalizadas" (Pollak 1992, 1989), relativas à vida social na ilha; ela não é um paraíso intocado, é o que restou de um passado marcado por conflitos e destruições ambientais ${ }^{7}$, e também por violência, pois o homem

6 O tema do caráter implícito e/ou subterrâneo de certas memórias não deve ser confundido apenas com o traumático - e, neste sentido, nos aproximamos de Pollak (1992) até certo ponto, uma vez que nos interessa muito mais o caráter sensível das imagens (míticas, poéticas, terrificantes, entre outras) correntes no universo amazônico, que vibram como experiências paisageiras locais: elas são reverberações imaginárias das potências da imagens compartilhadas por grupos que entrelaçam memórias coletivas e sociais, no sentido que Halbwachs (2003) dá aos termos, e que se entranham nos lugares. Por certo, algumas delas, traumáticas, inclusive, afloram em momentos de crise, engendrando conflitos e disputas, e silenciosamente contribuem para subverterem a lógica imposta por uma memória oficial de caráter social.

7 Há vasta bibliografia sobre o tema das florestas, das relações míticas, simbólico-práticas e de destruição que coletivos humanos estabeleceram com elas ao longo do tempo. Apenas para citar algumas, evocamos Harrison (1992), Perlin (1992) e Schama (1996). Ressaltamos que este não é o objetivo do debate proposto neste artigo. No caso de Cotijuba, sabe-se que a ilha "já perdeu $46 \%$ da sua floresta original", conforme Leão et al. (2007:30). 
é capaz de edificar obras significativas e também de destruí-las ou abandoná-las, deixando que o tempo reconfigure as paisagens do espaço (Simmel 1979).

"É necessário sair da ilha para ver a ilha", narrou José Saramago (1998), no conto “A ilha desconhecida”. A primeira visita à ilha foi suficiente para percebermos a profundidade dessa afirmação, pois as memórias narradas pelos mais antigos narradores do local suscitaram imagens e figuras arquetípicas que contribuíram para tessitura das paisagens da ilha de Cotijuba.

As reflexões, portanto, seguem a perspectiva de compreendermos as relações entre as memórias compartilhadas do lugar, cotejando o campo das narrativas fantásticas e do imaginário, no sentindo de abrangerem as representações acerca da ínsula - e, por isso, da antropologia produzida no espaço das modernas sociedades complexas urbanoagrárias brasileiras -, capazes de mobilizar uma constelação de imagens, que dura no tempo e evoca formas de pertença ao lugar.

Caminhamos para escavar a areia à procura de conchas, com o destino à praia do Farol, pois no caminho íamos conhecer Dona Zilda, uma contadora de histórias indicada por um morador local. Ele havia dito que essa senhora era moradora antiga da ilha e que sabia muitas histórias sobre o lugar. A partir dela, conhecemos outros narradores antigos que residem há muito tempo em Cotijuba.

\section{DONA ZILDA}

"Nas águas barrentas, confusas, da tua memória cansada, febril..." (Siqueira 2008).

Dona Zilda (72 anos) vive nas proximidades da praia do Farol. Trata-se de uma moradora antiga da comunidade de mesmo nome e que, segundo nos informaram em Icoaraci, sabia muitas histórias sobre o lugar. Naquela localidade da ilha, o ritmo cotidiano é bucólico, menos intenso, com aparência marcadamente rural, distinguindo-se dos modos de vida mais acelerados de alguns pontos da ilha onde a existência de um núcleo urbano é evidente, inclusive contando com a presença de turistas vindos principalmente da cidade de Belém e do distrito de Icoaraci. As ilhas situadas no entorno da metrópole apresentam diversos coletivos humanos detentores de práticas comumente denominadas de tradicionais, que, em um primeiro momento, poderiam ser pensadas como opostas ao modo de vida urbano, mas que remetem à diversidade da ocupação humana no que se refere ao processo de domesticação do espaço e do tempo (LeroiGourhan 1965).

No dia em que a entrevistamos, Dona Zilda estava no quintal, lavando roupas. Realizava as suas tarefas em um local amplo, cheio de plantas de diversos tipos, árvores e flores, havia dois cachorros presos e um papagaio, que logo começou 
a gritar. Ela disse que cuidava sozinha daquele espaço doméstico. Quando estava bem-disposta, até capinava, para não deixar o mato crescer em demasia. Dona Zilda sorriu enquanto permaneceu sentada num banco, enxaguando algumas roupas, e indicou que sentássemos num banco próximo a ela. No período em que permanecemos em sua morada, a senhora ia de lá para cá sempre atarefada e, sorridente, tratava peixes para o almoço, cuidava da família. Em frente à casa, as crianças brincavam, algumas se dirigiam à escola.

Dona Zilda possui cabelos brancos e pele negra. Contou que a mãe estava grávida quando veio para Cotijuba, e que a senhora era originária das proximidades da ilha. Segundo ela:

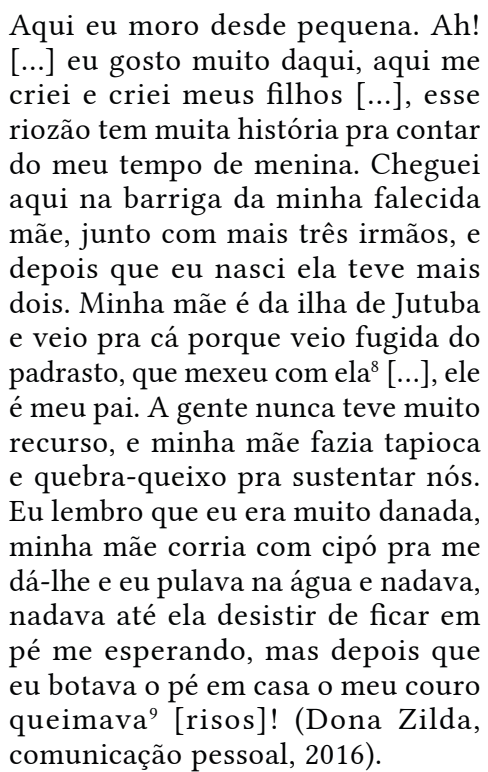

A senhora nasceu em Cotijuba, assim como os seus filhos. São quatro filhos, um homem e três mulheres. Deles todos, apenas Célia mora com a mãe, bem como os filhos de Célia. A senhora contou um pouco de sua vida, das desilusões, do trabalho cotidiano e de como criou seus filhos:

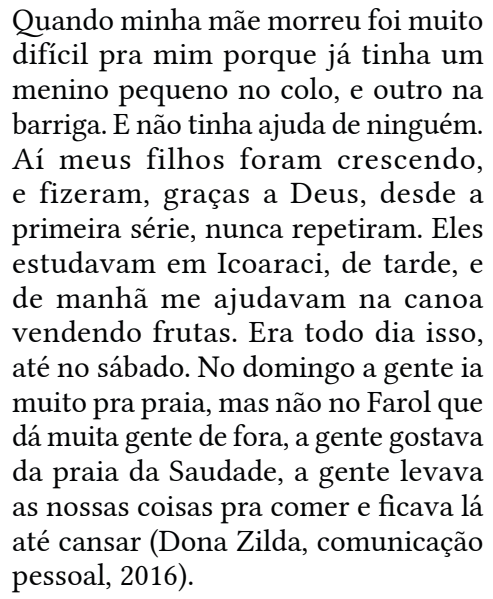

Dona Zilda narrou uma história que a mãe contava, que denominou de "a história da velha do balde". Uma narrativa de assombração e mistério, cujo episódio aconteceu na ilha de Jutuba, localizada em frente a Cotijuba, como segue:

Perto da casa dela tinha uma casa grande. Numa noite tinha fugido uns porcos do chiqueiro que minha avó criava, engordava pra vender, e os porcos começaram a fazer muito barulho atrás da casa. Como minha avó era muito velhinha, minha mãe chamou a irmã mais velha pra ir com ela. A noite tava muito clara, era lua

8 Expressão que significa que a mulher teve sua primeira relação sexual.

9 Expressão que designa a ação de apanhar, levar uma surra de alguém. 
cheia. Aí, quando elas recolheram os porcos e tudo, a minha mãe entrou, foi lavar os pés que tinha sujado muito. Aí, a irmã dela ficou pra fora olhando a lua e quando foi assim, depois mamãe foi atrás dela, atrás da casa, olhou pro lado que morava os outros vizinhos, onde tinha nascido uma criancinha. E é, e nessa parte da casa tinha uma parede com um buraco muito grande. Então, ela ficou olhando assim, quando ela viu, tinha uma senhora abaixada, olhando naquele buraco, a casa toda fechada, porque era fora de hora, e ela não correu, não: ela ficou olhando pra mulher. Aí, a velha levantou assim, mamãe não sabia se ela viu ela ou não. Quando ela levantou, ela viu que era uma senhora vestida de branco, com um balde na mão, não botava os pés no chão e o cabelo muito comprido e usava assim como se fosse uma partinha10. Ela olhou bem pra aquele buraco, olhou pro lado que minha mãe estava, de repente ela abriu os braço, assim... Quando ela viu, ela saiu voando, aí ela ficou olhando aquele negócio voando, era como se fosse um pato muito grande que saiu voando, voando, voando. Aí, ela teve muito medo, entrou pra dentro de casa, num falou nada nem pra minha avó, nem pra irmã dela; no dia seguinte é que ela foi contar pra minha avó o que tinha acontecido. Aí minha avó pegou e disse pra ela assim: "Oh, lá naquela casa tem uma criancinha que não foi batizada ainda e pode ser uma bruxa que veio lá pra mexer com a criança, então, vamos lá ver o que aconteceu". Aí, elas foram na casa, chamaram a dona da casa, ela veio, atendeu elas, mas elas não contaram nada. Aí, elas foram ver a criancinha, ela tava bem, tava tudo bem. Aí, mamãe queria contar. Aí, ela pegou e falou pra mulher assim, se ela não tinha visto nada à noite, não tinha sentido nada, assim [...]. Ela disse: "Não, por que você tá perguntando isso?". Mamãe disse: "Não, porque eu saí no quintal fora de hora e me pareceu que eu vi uma coisa aqui no, na parede de sua casa, olhando no buraco, parecia uma senhora curvada...”. Aí, ela disse a mesma coisa: "Então, você não viu uma senhora, você viu uma bruxa e essa bruxa veio pra sungar o sangue da criança, mas como eu tinha colocado uma tesoura aberta embaixo da rede do meu filho, ela não teve como chegar perto. Ainda bem que, graças a Deus, o meu filho foi salvo!" (Dona Zilda, comunicação pessoal, 2016)

Dona Zilda contou que essa história lhe marcou muito. Na época, ela disse que passou muito tempo assustada devido ao que ouvira. Aqui, as reflexões benjaminianas (Benjamim 1994) ajudamnos a ponderar sobre como o narrador extrai conhecimentos de fatos distantes no passado ou distantes no tempo para construir as suas próprias experiências e impressões sobre os lugares e os fenômenos sutis a eles relacionados. Portanto, narra acerca das circunstâncias de que tomou conhecimento envolvendo outrem, ou simplesmente narra uma história como experiência pessoal.

Naquele mesmo encontro, ela contaria sobre "um bicho peludo que ficava em cima do ingazeiro" (Dona Zilda, comunicação pessoal, 2016). Suas duas filhas, inclusive, teriam visto o ser estranho. A idosa narrou a história e revelou que esse ingazeiro permanece até hoje no fundo do seu quintal, apontando o local com o dedo indicador.

10 Termo comum em algumas comunidades interioranas, que significa parte do cabelo que cobre a testa, sendo sinônimo de franja. 
$\mathrm{Na}$ sombra daquele ingazeiro ali a gente escutava um barulho de um bicho grande, tipo um urso. Sei lá. Isso arrepiava a gente. Era só botar o pé no quintal fora de hora que a gente ouvia! Aqui perto os moradores antigos sabem dessa história. Um dia, quando eu fui pegar uma folha de canela para fazer chá pra minha filha, eu vi só uma sombra de um bichão em pé, muito grande, era largo e a cabeça parecia de cachorro, mas aquilo não tinha como ser um cachorro. Eu me espantei e gritei e aquilo correu pra cima do ingazeiro. $\mathrm{Na}$ época, os poucos vizinhos vieram me acudir, eu estava bem, foi só o susto mesmo! Eles olharam com a lamparina pra cima do ingazeiro e aquilo sumiu. Depois de uns três meses, mais ou menos, aquele barulho voltou a aparecer, vindo de cima do ingazeiro. Só parou quando eu fiz umas novenas para São Lázaro. Rezava muito pra aquilo parar de aparecer nesse quintal. São Lázaro escutou minha prece. Eu não ouvi mais nada, mas às vezes dá uma sensação estranha quando eu venho só aqui pro fundo. Um medo. Acho que é porque eu me lembro do que aconteceu (Dona Zilda, comunicação pessoal, 2016).

A cada espaço do quintal palmilhado, Dona Zilda tecia uma nova história, as memórias se reconfiguram porque aqueles que as mantêm, por certo, mudam diante das vicissitudes do tempo e dos intuitos que o espaço suscita, resultando numa memória movida por caminhos específicos, ampliando-se para o armazenamento de uma qualidade de informações portentosas, variadas e rigorosamente ordenadas (Yates 2007).

Um quintal entendido como um lugar praticado ao longo do tempo revela-se como um receptáculo de memórias entranhadas a partir das experiências sensíveis dos habitantes de uma determinada localidade com humanos, não humanos e sobrehumanos, que constituem uma paisagem de profundas reverberações imaginárias. Neste sentido, o seu quintal, enquanto uma construção humana, possui um repertório de histórias, cujas muitas descrições que ela fazia vibravam, em contraposição a certas imagens presentes na ínsula, tais como a de que "aqui era só mato" - evocando uma natureza selvagem - e "ali tinha um presídio" - indicando um processo de ocupação, de certa urbanidade -, que ressoavam naquela paisagem.

Direcionando um olhar crítico aos pressupostos que atuam na percepção das relações "homemmundo", segundo a lógica cartesiana, Ingold (2000:189) apresenta a "paisagem" através de um modelo de conhecimento que tem como base a indissociação do indivíduo do meio em que se insere, de sua percepção como "ser-no-mundo", que habita e é habitado nesta interação. A consequência mais direta de sua abordagem teórica, voltada a definir precisamente o que o termo paisagem significa, demonstra que o ser humano está situado em dado contexto por diversas formas ecológicoculturais de engajamento.

Quanto às ruínas do presídio, cuja presença é notória quando se chega a Cotijuba, Zilda diz que não gosta daquele espaço, porque "acolá houve muito sofrimento!" (comunicação pessoal, 2016). Segundo a senhora, o 
local é mal-assombrado. Assim, suas memórias sobre o presídio foram tecidas numa tensão entre sentimentos de medo e pena: medo pela obscuridade histórica que aquela construção representou; pena pelo sofrimento dos condenados que por ali viveram. Sobre o antigo educandário, ela diz que:

\begin{abstract}
Muita gente daqui sabe a história desse lugar. Eu nunca gostei dele. Tem uma carga pesada, que dá medo! Mas ele sempre fez parte daqui. Quando eu era mocinha, eu tinha medo dos presos daí, porque eram homens maus que vinham pra cá ser castigado. Minha mãe sempre dizia pra ficar longe de lá, eu não passava nem perto. Depois, quando fui crescendo, eu comecei a ficar com pena daqueles preso. Eu não entendia muito. Esse presídio é mal-assombrado, até hoje a gente escuta os preso, que viviam aí, gritando e pedindo socorro. É verdade! Quer ver? Passa depois das seis horas da tarde por aí que você vai ver, e vai sentir muita coisa. Só de você tocar nessas paredes caindo, a gente já se arrepia tudo. Aí teve muito sofrimento, e a alma dos presos ainda estão preso aí! (Dona Zilda, comunicação pessoal, 2016).
\end{abstract}

Receio e pesar misturados são as duas formas de sensações despertadas toda vez que ela passa pela frente das ruínas. Ela conta que se arrepia quando passa diante do lugar porque naquela materialidade arruinada ainda é possível sentir todo sofrimento que existiu no local, segundo a sua perspectiva. Isso parece lhe incomodar. Conta que as pessoas que moram em Cotijuba têm muitas histórias sobre almas que habitam as ruínas. Porém, ela afirma que nunca viu nada e que apenas sente uma energia pesada quando passa nas proximidades do lugar.

Há de se destacar na voz de Dona Zilda, paulatinamente, a tessitura de sua narrativa diante de fatos, lembranças e esquecimentos que constroem a memória social da ilha de Cotijuba e se entrelaçam àquela de caráter mais coletivo. E a partir desse jogo de memórias, a idosa vai revelando seu modo de vida e as histórias do seu lugar, recuperando as memórias de um período histórico e político paraense, aliadas às suas tradições de contar histórias prosaicas, cotidianas.

Dona Zilda reforça que a ilha de Cotijuba foi marcada por esse acontecimento histórico que foi a presença de presos, inclusive políticos, naquele contexto. Ela diz saber pouco sobre o cotidiano dos presos naquela época que o educandário e o presídio existiam. Parece que há certo silenciamento ou, ainda, uma espécie de "desmemória" proposital acerca do passado da ilha, representada no temor em relação ao presídio que ali foi erguido outrora. É possível perceber um olhar distante de Dona Zilda, algo lembrado apenas por e para ela, que não precisa ser compartilhado naquele momento de conversa conosco, são silêncios e segredos seus.

Mas ela retoma o assunto sobre o presídio. Diz que as pessoas têm mais medo de passar à noite em frente às ruínas do que de passar em frente ao cemitério: 
A história que mais contam desse presídio é sobre as visagem que mora aí. Tem gente que já viu visagem sem cabeça. Esse presídio dá mais medo do que o cemitério. O pessoal passa tarde da noite em frente do cemitério e se benze, e nada acontece. Agora passa sozinha aí na frente desse presídio de noite, égua! Dá um medo danado! [risos] Porque morreu muita gente aí sofrendo. Acho que a alma deles não consegue se libertar desse mundo. Esse lugar está caindo, mas tem muita gente que vem aqui saber sobre ele, como você, fazer estudo, tirar fotografia (Dona Zilda, comunicação pessoal, 2016).

As experiências narradas por Dona Zilda traduzem toda uma rede de significados e de significantes que habitam a experiência coletiva das comunidades que compõem a ilha de Cotijuba, num dos mais expressivos períodos da história da localidade, e que se relaciona à presença dos presos em seu cotidiano. As memórias da narradora são revividas e ritualizadas, numa tentativa de identificação por parte dos moradores da ilha, o que lhes conferem aspectos de lugares feitos de esquecimentos e de lembranças: "Os lugares de memória são, antes de tudo, restos” (Nora 1993:10). Por muito tempo, a ilha foi relegada pela população belenense, por ter sido um local que abrigava presidiários vindos da cidade de Belém.

As narrativas revelam, sobretudo, a forma pela qual Dona Zilda aprendeu a lidar com a sua condição de narradora das suas vivências. Os fatos sobre a ilha contribuem para o entendimento dos processos de construção de identidades e relações subjetivas entre os moradores do lugar ligados a um território afetivo de pertencimento, onde paisagens fantásticas vibram como dimensões das memórias dos lugares (Silveira 2004). Nessa grande maré de fluxos de imagens, os "dramas sociais" ${ }^{11}$ (Turner 1996) narrados permitem que se façam relevantes descobertas acerca das histórias da ilha de Cotijuba. A narradora conta também sobre as histórias que ouvira de seu pai:

[...] meu pai dizia que lá pra banda
do Vai Quem Quer tem dinheiro
enterrado. Ele sonhou que um padre
tava dando dinheiro pra ele. Ele tava
de branco, com roupa branca e aquela
bata, bem assim. Aí, ele disse pro meu
pai assim: "Eu te dou esse tesouro
pra ti, mas só tu pode cavar!". Esse
padre disse pro meu pai, embaixo de
uma mangueira que tem bem assim,
quando desce pra ir pra praia lá. Essa
mangueira tá lá ainda. Meu pai morreu
e nunca foi lá ver se era verdade (Dona
Zilda, comunicação pessoal, 2016).

O olhar lançado sobre o espaço insular por Dona Zilda transita por sentimentos opostos, por vezes ambíguos, isso porque Cotijuba, com a sua exuberância paisagística natural que atrai muitos visitantes à procura do exótico amazônico, do mesmo modo traz consigo o exuberante e o monstruoso. Na opinião de Dona Zilda:

11 "Os dramas sociais rrepresentam uma complexa interação entre padrões normativos estabelecidos no curso de regularidades profundas de condicionamento e da experiência social e as aspirações imediatas, ambições ou outros objetivos e lutas conscientes de grupos ou indivíduos no aqui e no agora" (Turner 1996:21-22). 
Essa ilha é muito bonita! Foi aqui que nasci, cresci e aqui que vou morrer um dia. Aqui a gente tem praia, igarapé, fruta, mato, terra. O que mais eu ia querer? [risos] Claro que a gente às vezes tem dificuldades. Mas o que minha mãe me ensinou foi trabalhar pra conseguir o que eu quero. E assim fiz e ensinei pros meus filhos, e ensino pros meus netos [...], só o que a gente leva dessa vida são as lembranças! (Dona Zilda, comunicação pessoal, 2016).

Dona Zilda seleciona as histórias que considera boas para serem narradas aos pesquisadores. Trata-se de uma narradora que traz histórias de suas vivências e dos acontecimentos atrelados a episódios envolvendo eventos de caráter fantástico, que fazem parte do cotidiano dos moradores da ilha. A performance da narradora sempre esteve relacionada ao olhar profundo que trazia consigo, pela voz pausada que evocava um sistema de crenças populares e por um repertório de representações e imagens ligadas à sua narrativa riquíssima em elementos culturais amazônicos. A tessitura de sua narrativa une os fios de suas memórias àquelas que ouviu dos outros, produzindo emaranhados criativos com outros fios que alinhavam as narrativas de Dona Zilda:

Eu vivo aqui nesse canto, com a minha família. Tudo aqui era mato, tudo mato. Esse caminho que vai pra praia era tudinho mato. Só pouca casinha simples, uma aqui e outra bem longe. Era silêncio. Nós escutava bem a natureza. Agora não. Agora vem muita gente pra cá, muita gente que veio morar aqui. Era mato, areia e a praia. Tinha o cemitério e o presídio nos fundos daqui. Depois, foi amontoando gente e o cemitério foi feito mais pra lá. E esse presídio acabou e só ficou o lugar (Dona Zilda, comunicação pessoal, 2016)

Quando escutamos as narrativas dos antigos moradores da ilha de Cotijuba, percebemos que o reconhecimento dessas pessoas como narradores faz parte da posição que elas ocupam nas comunidades da ilha, como personagens e porta-vozes das memórias locais.

Dona Zilda, como muitas mulheres da ilha, disse que não teve muito estudo porque desde os dez anos ajudava a mãe a vender tapioca e quebra-queixo no terminal hidroviário de Cotijuba. Depois, na adolescência, ela e a mãe começaram a atravessar para Icoaraci, cedinho da manhã, para venderem frutas que colhiam na ilha: manga, jambo, ingá, tucumã, abricó e até caroços de açaí. Vendiam as frutas de acordo com a época de amadurecimento.

Assim, a venda da tapioca e do quebra-queixo ficava para o turno da tarde. A senhora contou sobre as peripécias do seu tempo de menina, do quanto gostava de passear de canoa em torno da ilha e de nadar no rio.

Atualmente, as frutas extraídas ou coletadas da ilha de Cotijuba que são mais procuradas nas feiras são o cupuaçu, o taperebá, o muruci, a jaca 
e a pupunha, entre outras. Na maioria das vezes, essas frutas viram polpas e são comercializadas pelos próprios moradores da ilha ou de Icoaraci. Existem outros elementos rentáveis extraídos da natureza da ilha, recursos como areia e madeira, os quais são utilizados como matérias-primas na construção de habitações no continente ${ }^{12}$.

Finalmente, durante as conversas com Dona Zilda, ela indicou outros narradores que seriam muito importantes para a pesquisa que realizamos, entre eles destacamos: o pescador Seu Dimas (morador da comunidade da Pedra Branca); Seu Lorival (um dos primeiros moradores da localidade denominada de Vai Quem Quer); além do dono de um armazém, Seu Raimundo Oito, que mora próximo à praia da Flecheira. Conversando com alguns deles, outros moradores antigos foram sendo indicados, e a maior referência entre eles era sem sombra de dúvidas Seu Jorge, do Vai Quem Quer, que mora na "ponta de cima da ilha". "Esse sim sabe muita coisa de Cotijuba!", comentavam.

\section{3. "O TEMPO TEM TEMPO DE TEMPO SER"13}

Seu Dimas reside na comunidade de pescadores chamada Pedra Branca, situada na praia Funda, próximo ao igarapé da Flecheira. Trata-se de uma pequena comunidade de pescadores localizada numa área denominada de Ponta de Baixo, nas proximidades de outra comunidade conhecida na ilha como Poção. Na localidade, a pesca de camarão é uma atividade muito cultivada pelas famílias que moram na comunidade da Pedra Branca. A fim de complementarem seu sustento, as pessoas trabalham a terra plantando couve, mandioca, macaxeira, coentro e outros produtos que fazem parte, junto com o pescado, do prato diário dos grupos familiares. A pesca do camarão é realizada nos furos e nos igarapés próximos às residências dos pescadores, onde também é possível encontrar o açaí e a bacaba.

Na casa de Seu Dimas, fomos recebidos por sua esposa, Dona Margarida, uma mulher jovem e muito simpática. Ela solicitou que entrássemos, pois seu esposo nos aguardava na sala. Ao adentrarmos na morada, pudemos perceber as dimensões sensíveis do espaço afetivo que há no interior das casas, no seu conjunto de coisas e, nestes termos, a tranquilidade que aí reside seria própria às imagens da casa, da morada como ventre ou gruta (Bachelard 1988), que produz aconchego.

O contato com o senhor ocorreu na ponte de Icoaraci, quando um dos autores passava

12 Aliás, os moradores é que geralmente constroem as suas moradias, como fica evidente na fala de seu Dimas (68 anos), pois, segundo ele: "Nessa vida a gente aprende a fazer tudo. Eu, praticamente, construí essa casa. Não me aperreio com nada não. Fiz até o primeiro grau. Minha vida sempre foi trabalhar” (comunicação pessoal, 2017).

13 Verso do poema "Pauapixuna", de Ruy Barata. 
pelo local e o escutou conversando com um amigo sobre Cotijuba, momento em que foi perguntado se morava nessa ilha e há quanto tempo. Ele respondeu que chegou a Cotijuba no colo de sua mãe. Ficou claro pelo breve diálogo que Seu Dimas possuía muitas histórias sobre a ilha. A partir deste encontro, resolvemos marcar um outro momento para conversarmos sobre a ilha e sobre as suas histórias. Combinamos, ele forneceu o número do seu telefone para acertamos a data.

Seu Dimas é um senhor com um jeito sério. É pescador e se diz orgulhoso do seu saber-fazer. Faz utensílios para pesca artesanal, tais como rede, tarrafa ${ }^{14}$, matapi ${ }^{15}$, batedor ${ }^{16}$, entre outros. Sustenta a família, composta de sua esposa, dois filhos e um neto. Seus outros filhos, três, moram em Belém. Ele tem pouco contato com esses filhos, que são fruto de seu relacionamento com a primeira esposa.

Naquele dia, o senhor estava sentando numa rede, esperando nossa chegada. Pediu para Dona Margarida servir café. Disse que sempre morou em Cotijuba e aprendeu o ofício e a confecção de materiais de pesca com o pai e um tio. Ele mostrou um gostar entusiasmado pela confecção de redes para pesca. Seu tempo é dividido entre a pescaria, a venda do pescado e a confecção de redes de pesca. Seu Dimas possui muita disposição em realizar seus afazeres. $\mathrm{O}$ senhor conta que:

Desde quando eu era assim, ó, pexixito
que eu vim pra cá. Aqui só não tem
dinheiro, mas força de vontade não
falta. Cheguei aqui em 1948 nos braços
da minha mãe que nasceu aqui, mas
tinha ido trabalhar em Belém e depois
que ficou grávida voltou pra cá pra
Pedra Branca. Tenho 68 anos bem
vividos, graças a Deus! Sou pescador
e sustento minha família com isso. Eu
comecei a pescar olhando: meu pai
me ensinava, o meu tio fazia as redes.
E depois eu aprendi a fazer as rede,
batedor, tarrafa [...]. Eu pesco mais
camarão (Seu Dimas, comunicação
pessoal, 2017).

Enquanto fumava um cigarro e se embalava numa cadeira, continuava contando sobre suas vivências e histórias de pescador, as aventuras de seus amigos no mundo da pesca. Histórias do mistério das águas que fazem os cascos virarem; histórias de amigos que apareceram, misteriosamente, abraçados mortos numa rede

14 É uma rede de pesca circular com pequenos pesos distribuídos em torno de toda a circunferência da malha. A tarrafa é arremessada geralmente com as mãos, de tal maneira que a mesma se estenda/abra o máximo possível antes de cair na água.

15 O matapi é um instrumento feito de fibra vegetal, retirado da palmeira jupati, muito comum na Amazônia para a cultura da pesca do camarão, que é uma atividade frequente na vida dos ribeirinhos.

16 É um instrumento semelhante ao arpão, sendo um pouco mais fino. Dotado de duas, três ou mais pontas com farpas, e usado na captura de pequenos peixes, moluscos e crustáceos. Assim como o arpão, a sua extremidade é fixada a uma vara de dois ou três metros, para manuseio. É muito empregado na pesca noturna. 
de pesca; histórias de um peixe grande, "piranha enorme", que apareceu ao seu pai; e também de uma árvore de embaúba que aparece e some dentro do rio. As águas daquele rio escondem mistérios, deixando marcas no coração do pescador, parecendo que um rio de emoções corria também dentro dele (Bachelard 1997).

Enquanto Seu Dimas ia narrando histórias, ficava evidente o quanto o cenário das águas constituía e aguçava a tessitura delas. Talvez, por isso, as ilhas são frequentemente associadas aos cenários idílicos, uma vez que podem ser consideradas locais com uma "poética das águas". Em Bachelard (1997), a água aparece como um ser total, pois tem corpo e voz, tem agência, traduz um dinamismo de formas. A linguagem bachelardiana das águas é uma realidade poética direta; os regatos e os rios sonorizam com estranha fidelidade às paisagens como dimensões sensíveis, evocam suas vibrações.

Vou te falar a verdade, eu e minha mulher, a gente fica sempre pensando a nossa vida aqui na ilha. E eu digo pra você, podia ser a melhor casa, o melhor apartamento, o que quer que fosse eu não troco por essa casa aqui. Não tem luxo, você vê, mas tudo que tem aqui, cada coisa foi colocada com o suor do meu trabalho da pesca. Por dinheiro nenhum no mundo, nenhum palacete, fazenda, prédio coisa nenhuma neste mundo. Nada, nada. Uma, porque eu acabei de criar meus filhos aqui e, outra, porque aqui foi um lugar que eu tive uma vida fantástica, uma vida... Como se diz? Uma vida de sonho, só num sonho eu posso ter de novo uma vida dessa. Sempre com muita fartura de peixe e camarão, eu não faço questão de carne, e nunca fiz, tem minhas plantação. Aqui eu fico bem pertinho do rio, eu sempre pesquei, eu pescava muito, ganho meu dinheiro, tem tudo que eu preciso pra viver [...], o custo de vida pra mim aqui é muito mais barato que em Icoaraci ou Belém, não tem nem comparação. Apesar que eu tenho minha casa, vivo bem com minha esposa, com meus filhos, com meus neto, tenho uma família maravilhosa. Fomo acostumado a viver na beira d'água, nós. Nós somos igual peixe, você tira da água e ele morre! (Seu Dimas, comunicação pessoal, 2017).

Na comunidade de pescadores da Pedra Branca, as narrativas sobre seres fantásticos que habitam as águas são elementos culturais presentes nos modos de vida desses pescadores. Na medida em que as narrativas são elementos relacionados às condições de vida dessa comunidade, elas refletem as táticas cotidianas dos coletivos em um contexto de transformações sociais.

As narrativas dos pescadores artesanais podem ir muito além daquelas que povoam as águas dos rios e igarapés da ilha. No campo da oralidade, mais fecundo ainda se imagina ser o mundo das águas, principalmente para aqueles que, de fato, encontramse ligados a ele. Quantas histórias os pescadores contam sobre acontecimentos que vivenciam nas águas? O que temem? O que enfrentam? A existência de muitas histórias em torno dos igarapés e do rio que banham a ilha anunciada por Seu Dimas reforça as nossas expectativas. 
Percebemos que naquela manhã Seu Dimas precisava sair para uma reunião com alguns pescadores. Dona Margarida o lembrou do compromisso. Ele retrucou dizendo que não estava com pressa, justificando para a esposa que já havia marcado um encontro conosco antes da reunião para a qual ele precisava ir. Ficamos um pouco desconcertados, afinal, não queríamos atrapalhar o seu compromisso. Entretanto, fomos tranquilizados quando ele disse que nossa presença ali também era importante, e que o tempo para ele não era ligeiro, o que nos fez lembrar o verso do poema "Pauapixuma", de Rui Barata: "o Tempo tem tempo de Tempo ser", e mais precisamente sobre o fato de esse tempo da memória ser diferente do tempo cronológico.

O narrador destacou que sabe muitas histórias. Narrativas que emergem nas animadas rodas de prosa, relembrando a "vida de antigamente" na ilha. Como pesquisadores, ouvimos muitas histórias e contamos algumas, assim como Cascudo (1995) que, em suas viagens, fazia amigos e ouvia histórias ao pé do ouvido - muitas informações sobre "causos" que embalaram o sono e assustaram gerações e gerações. Dentre elas, várias falam de fantasmas, espíritos, enigmas, acontecimentos incompreensíveis e assustadores que permeavam as aventuras pelo rio, pela mata, além do confronto com animais selvagens:
História de pescador... Tem é muita história de pescador, não dá nem pra mentir. [risos] Tem uma história, mas não é mentira! Aconteceu mesmo! Um dia a gente vinha pelo igarapé da Flecheira. Porque a gente subia lá na ponta da praia, quando a pesca tava aberta. A gente subia... Você conhece ali? Subindo pela praia? Aí a gente vinha andando, andava o dia inteiro e quando chega lá pelas três ou quatro horas, cê encosta os barcos pra armar as barracas, assim pra poder pescar aquela noite e depois vim. Aí, teve um lugar que a gente encostamo... Não, nós ia encostar. Era uma mata fechada, muito fechada, não tinha como ter sobrevivência num lugar daquele. Não tinha como ter uma pessoa pra fica lá dentro. Aí nós fomo encostando os barco e aí... sabe quando parece que quebra um pau, assim? Um barulho alto como se uma pessoa tivesse quebrado um pau... mas grosso assim. E depois tacou assim na água, a gente viu cair na água. O outro pescador olhou pra mim, eu olhei pra ele. Eu fiz assim, com a mão. Aí de novo, outro pau. Ele: Não vamo encostar aí não. Mas era uma mata! Aquilo arrepiava a gente assim de medo. Não tinha como ali ter alguém. E nós fomo embora e paramo bem mais pra baixo e pro outro lado. Já não acampamo mais daquele lado do rio. E aquela semana nós não peguemo nada. Parece até coisa, num pescamo nada. Foi que nem um azar aquilo lá. Foi viagem perdida. E aquele tempo não acontecia isso de ficar uma semana sem pescar nada. Você ia e pegava. Hoje, sim, acontece muito de perder a viagem (Seu Dimas, comunicação pessoal, 2017).

Prosseguimos a conversa. Perguntamos a ele se já havia morado em outro lugar. Ele respondeu que nunca teve vontade de deixar Cotijuba. Seu Dimas ressaltou que a ilha é um lugar muito bonito, onde ele gosta muito de morar: 
Conheço muitas ilha aqui perto, mas nunca tive vontade de sair daqui. Minha mulher, filhos e netos também. A maioria da gente daqui da comunidade, mesma coisa. $\mathrm{O}$ nosso lugar é nosso lugar, não tem como falar muito. Aqui a gente não samo rico, a gente trabalha pra viver e Deus vai abençoando nós. Muita gente vem pra cá passear e se encanta por aqui, porque aqui é bonito mesmo. É ou não é? Gosto mais de sossego, quase não vou pra praia, minha lida diária é mais com a pesca e em casa mesmo, mas claro que gosto de dar uma voltinha no trapiche de vez em quando pra saber das novidades [risos] (Seu Dimas, comunicação pessoal, 2017).

Seu Dimas dizia gostar do sossego que sua comunidade oferece. Afirmava que não poderia ficar rico sendo pescador, mas gostava de seu modo de vida. No seu quintal, há uma pequena horta onde sua família planta couve-flor e chicória, hortaliças que ajudam a complementar as refeições diariamente.

Seu Dimas comentou sobre o educandário e o presídio que existiram no local. Ele nos contou que os presos eram transportados para a ilha de Cotijuba por conta da superlotação do presídio de Belém. O narrador também revelou que conheceu um pesquisador, um historiador, que confirmou que os presos que chegavam à ilha de Cotijuba eram torturados. Seu Dimas diz ser um absurdo uma ilha tão bonita como Cotijuba ser considerada uma prisão, um castigo, um lugar que nenhum presidiário gostaria de ir.
O pescador ainda mencionou que os presos mais perigosos vinham para ilha e os seus moradores ficavam desprotegidos. E, por conta disso, os ilhéus mantinham distância dos presidiários. Contou-nos que atualmente no lugar onde existia o presídio:

Tem gente que já viu marmota por aí
quando passa tarde da noite. Eu nunca
vi! Parece que tem umas correntes
que se escuta arrastar, voz de gente
conversando, e até barulho de abrir
e fechar grade. Quando a pessoa olha
não tem ninguém, tá tudo vazio. O
caboco corre [risos], todo mundo sabe
disso. Minha comadre outro dia passou
por ali e se sentiu mal, com dor de
cabeça, um arrepio no corpo. Isso foi
umas nove da noite. Mas não é pela
frente, é por detrás do presídio, que
ninguém passa. Lá é que faz visagem
mesmo (Seu Dimas, comunicação
pessoal, 2017).

O senhor relatou acerca das dificuldades que os presos enfrentavam ao tentar fugir da ilha. Além das grades e paredes que os prendiam, os presos, se passassem pelos obstáculos materiais que compunham a estrutura do presídio, ainda precisavam enfrentar as águas caudalosas como mais um empecilho. Seu Dimas afirmou que a maioria dos presos que conseguia fugir do presídio se lançava nas ondas desse rio, porém muitos morriam afogados ou eram devorados por algum animal aquático. Tais histórias também eram ouvidas por um dos pesquisadores, quando ia a Cotijuba nos períodos de férias escolares. Por um tempo, Seu Dimas ficou calado, de cabeça baixa. 
É provável que ele saiba muitas histórias tristes envolvendo o sofrimento dos presos nessa ilha.

Ele contou também que os presos trabalhavam na ilha e que cultivavam hortas para contribuir nas suas refeições. Seu Dimas disse que nessa época ele era garoto e já ajudava no sustento da sua família, com a pesca. Nesse momento, acendeu outro cigarro e pediu mais um café. Dona Margarida relembrou o compromisso com os demais pescadores. Ele disse que eles podiam esperar, pois a nossa prosa 'não carecia' de ser rápida. Para Seu Dimas, Cotijuba é um lugar abandonado pelo poder público, como muitos outros lugares na cidade de Belém. Ele alertou, principalmente, sobre os perigos de assaltos e outras violências que vêm ocorrendo, devido ao abandono do patrimônio público, como é o caso do antigo presídio na ilha.

O problema da segurança na ínsula reforça a utilização do termo ilha, no discurso de Seu Dimas: "tamo tudo ilhado aqui". O termo é utilizado como sinônimo de demarcação das suas fronteiras, para ratificar a ideia de isolamento, de um lugar abandonado, no caso, pela administração pública municipal. Trata-se de uma insularidade geográfica que irá se desdobrar, particularmente, nos tantos desafios que os moradores da ilha enfrentam no cotidiano para exercerem a sua cidadania, não raro precarizada pelo descaso que experimentam.
A casa de Seu Dimas encontra-se próximo à beiro do rio, aproximadamente no meio do caminho para a comunidade do Vai Quem Quer. No caminho para casa do pescador, as moradias são dispostas em terrenos grandes. $\mathrm{Na}$ entrada da casa de Seu Dimas, permanece ancorada a sua canoa. Ele enfatizou muito o fato de ser pescador: "Nasci na ilha. E sempre trabalhei com pesca. Antigamente eu caçava também, mas agora nem tem quase bicho e também estou velho pra isso. Sempre pesquei toda a vida" (Seu Dimas, comunicação pessoal, 2017). Seu Dimas olhou o relógio e sorriu por estar atrasado para sua reunião.

\section{SEU JORGE: ILHA-PRESÍDIO (A MORADA DAS ALMAS) E SEUS FANTASMAS}

Aí, antigamente, já fazia fantasma. Gritava pra lá, batiam panela, barulho pelas paredes. Isso tudo tinha lá. Isso uma vez eu vi. Eu fui viajar com meu tio, ele era piloto de uma barca dessas lá. Aí, como ele viajava pra Belém, eu tinha que ir pro exército, era o dia de eu me apresentar lá, que era chamada [...]. Aí, eu tinha que dormir lá que até duas horas já tem gente no Ver-o-Peso, aí eu ficava já lá, ao menos ia chegar bem cedo lá na fila. Nesse tempo, lá tinha o negócio de uma praçazinha lá [próximo ao presídio da ilha]. Assim era a parede da cozinha do prédio. Isso era tarde, era uma hora mais ou menos. Aí, estavam lá pra dentro mexendo na cozinha, era barulho de panela e tal. Olha que eu faço! Querendo ir lá pedir um café, eu queria entrar lá pra pedir um café, na imaginação minha. Aí, o titio estava lá pra canoa, eu pensei: vou já lá com ele. Eu perguntei pro titio se já estava na hora de pedir um café. O pessoal está na cozinha já lá mexendo. 
Ele arregalou o olho e me disse: que cozinha rapaz? Deita aí e dorme que está tudo fechado ainda, não tem ninguém lá (Seu Jorge, comunicação pessoal, 2017).

Uma marca que a ilha traz do seu passado histórico refere-se às memórias sobre a penitenciária, construída em 1968, sendo que, por algum tempo, educandário e presídio coexistiram. Tais edificações constituem um acervo de patrimônios e memórias que, seguindo a abordagem sugerida por Myrian Sepúlveda dos Santos (2005), sobre o tema do patrimônio comunitário e coletivo, mereceria a devida atenção quanto à sua preservação e conservação no contexto metropolitano. O policiamento ostensivo e as fugas frequentes de prisioneiros representaram um controle indireto do fluxo de visitantes e da expansão da população local. Porém, logo o educandário foi extinto e a ilha se transformou em ilha-presídio, recolhendo condenados e presos políticos, adultos e menores, com um sistema penal violento e arbitrário.

Bem assim tinha um portão que era o retiro dos presos. Aí, outros tipos de pessoas não moravam não. $\mathrm{E}$ tinha $\mathrm{o}$ colégio lá na frente. Vivia trocando de diretor para diretor. Aí, foi mudando as coisas por causa que houve um abandono aí, e deixaram o casarão lá, e as pessoas destruíram. Destruíram esse daqui também, na época esse terreno aí, ele era do Zacarias de Assunção. Era desse pessoal aí, era o coronel, general Zacarias da
Assunção. Era dele esse terreno, que é o terreno desse casarão aí. Mas, agora já invadiram tudo e tomaram tudo, aí já não sei mais de nada (Seu Jorge, comunicação pessoal, 2017)

Aí, o povo conta que já viu alma penada aí. Eu nunca vi, graças a Deus, mas sinto que tem alguma coisa aí nessas paredes. O pessoal conta que ouve gritos e barulho de corrente, de grade, de choro [...]. Cotijuba foi marcada com isso. Era pros presos não fugir e se fugir eles tinham que nadar muito pra se salvar. Contam que o nome da praia do Vai Quem Quer é porque se o preso não confessar, os guardas diziam: vai quem quer. Era pra ser torturado [...]. E muita gente acha que é porque a praia é muito longe e antigamente a gente ia a pé mesmo [risos] (Dona Zilda, comunicação pessoal, 2017).

Esse fato povoou muitos imaginários acerca da ilha e Cotijuba passou a ser considerada uma ilha-presídio, mesmo depois da desativação do mesmo, fazendo com que as pessoas mantivessem distância do lugar. Segundo Seu Zé, em 2005 faleceu o último "preso" da ilha. Porém, segundo algumas narrativas sobre as ruínas do lugar, os fantasmas dos antigos presos ainda "perturbam" quem “mexe com eles". Quem não acredita acaba sofrendo alguma punição.

Muitas narrativas são tecidas em relação às vivências dos antigos presos. Em uma das vezes que estávamos na ilha, conhecemos Seu Zé Maria, um simpático vendedor de sorvete que diz conhecer, através do irmão, algumas histórias sobre o presídio: 
Seu Zé Maria, morador da ilha há 43 anos conta que seu irmão mais velho foi um presidiário na ilha de Cotijuba. Diz que conseguiu escapar da ilha três vezes, e só retornou definitivamente a ela após a Ditadura Militar, onde pôde construir família, e viver tranquilamente na ilha. Seu Zé Maria conta sobre as histórias que seu irmão lhe narrara com o olhar penetrante diante da ruína do antigo presídio (Trecho do Diário de Campo).

Após anos, em 1977, com a inauguração da Penitenciária Estadual de Fernando de Guilhon, na cidade de Belém, a Colônia Penal de Cotijuba foi desativada. Assim, a história da ilha mudou quando a Constituição Brasileira de 1988 transferiu Cotijuba ao domínio municipal da capital paraense. Em 1990, a ilha de Cotijuba foi transformada em Área de Proteção Ambiental, pela lei municipal. Por esse último acontecimento, os visitantes da ilha são atraídos pela biodiversidade do local, pelo espaço turístico preservado e por suas características ecológicas.

Agora, só ficou as histórias desse presídio. Essas parede caindo aos pedaços. O pessoal diz que é patrimônio, né. Isso é feio demais. Deixa nossa ilha feia [...]. Aí, tinha preso que era torturado mesmo. Se ouvia grito. Agora, também dizem que quando morria um preso só fazia jogar na água pra bicho comer. Era sim. Tinha uns que tentava fugir nadando. Não sei se conseguia. O cara tinha que ser muito bom. Eu não conseguia nadar tanto. Até o Jutuba é longe. Imagina até em Icoaraci! Tem canal. É perigoso. Você vê tanta notícia de gente que se afoga na praia, ainda mais nesse riozão (Seu Zé, comunicação pessoal, 2017).
Segundo Silveira (2004:631), o imaginário fenomenológico das ruínas nas narrativas emerge de um tempo mítico, onde os sonhos guardam o lugar do enterramento dos tesouros, até que alguém "a partir da revelação onírica o receba como dádiva”. A revelação ao narrador, em sonhos, permite o acesso ao tesouro. As narrativas acerca de tesouros enterrados na ilha afloram do imaginário de muitos moradores do lugar. Portanto, o imaginário fantástico dos ilhéus é oriundo desse reservatório de imagens percebido na presença onírica como potência capaz de falar também sobre as turbulências do tempo. Esse mistério insular, do enterramento de tesouros, reforça a imagem da ilha enquanto guardiã de tesouros. Assim, as imagens dos tesouros enterrados aparecem nas narrativas fantásticas, recorrentes nas memórias dos antigos moradores de Cotijuba.

Do ponto de vista da história ocidental, por muitos anos, quando não existia registro escrito, as narrativas eram feitas oralmente, e cada trama produzia efeitos diferentes, dependendo do repertório de fatos associados às imagens de quem as narrava em determinado contexto sociocultural. Na Idade Média, os camponeses, por exemplo, sentavam-se à beira das fogueiras para ouvir enredos maravilhosos. Sabe-se que, numa comunidade narrativa, os contadores de histórias possuem papel de destaque, mantendo vivas as memórias 
coletivas do grupo e muitos deles instituem uma base identitária como forma de testemunho diário e regular de sua pertença aos lugares praticados ao longo do tempo (Certeau 1994).

O narrador prepara a plateia para a narração. Para Silveira (2004), os papéis são definidos na própria adesão aos fatos de narrar e escutar como acontecimentos sociais que derivam no compartilhamento de imagens que emanam das narrativas, e vice-versa. Nas histórias em que o narrador ficou frente a frente com um ser fantástico, forma-se uma paisagem-memória específica que vibra seus enraizamentos nos lugares.

Nesse sentindo, o assombro, ou visagem, é um fenômeno que se desdobra em narrativas fantásticas que envolvem acontecimentos causadores de pavor, medo e até angústia nas pessoas que experimentam uma relação tensional com ele, e que posteriormente será narrado como um episódio terrificante pelo narrador ou por outro que o ouviu numa roda de conversa. Ouvir e contar dinamizam as imagens fantásticas e tecem laços afetivo-cognitivos entre grupos humanos, e deles com as paisagens vivenciadas, produzindo éticas de relação com os lugares que passam pelo respeito, evitamento ou mesmo pela busca de proximidade em função de obtenção de uma graça de parte do ente que constitui certas dimensões sensíveis daquela paisagem.
$\mathrm{Na}$ ilha de Cotijuba, as narrativas, de maneira geral, têm se prestado muito fortemente, ao longo do tempo, a uma vasta série de construções simbólicas que, até certo ponto, ultrapassam as narrativas sobre o lugar e se misturam, envolvendo-se aos fluxos de água doce. Nestes termos, as narrativas veiculadas pelos coletivos vibram e significam naquele contexto, conectam-se em diversos aspectos ao cotidiano da ilha, às memórias entranhadas nos lugares, como as que Seu Jorge conta sobre certas vozes que assombram quem vai pelo horário de meio-dia ao igarapé da Flecheira:

Seu Jorge: Tem outra história aqui no igarapé. Isso aí é hora de meio-dia. Qualquer pessoa pode ver.

Neto de Seu Jorge: Huuum! Fala pra eles, que eu não acreditava.

Seu Jorge: Eles foram comigo pra lá. E também ouviram que tem vozes conversando. Nesse igarapé que passa aí atrás.

Neto de Seu Jorge: Meio-dia eles ficam conversando e roçando, o nome já é Diálogo dos Amigos. Depois do meiodia é selado, eu vi essa arrumação! Eles falam e conversam pra lá.

Seu Jorge: Um dia quando eu cheguei aqui era umas cinco horas, e eu fui colocar matapi no igarapé, eu fiz as coisas depressa e saí, peguei a canoa e fui me embora. Quando eu chego que nem esse cajueiro aqui, eu na canoa e lá tem uma seringueira grandona. Eu estava lá com matapi, e quando eu ouvi uns caras que acharam graça lá atrás! Acharam graça. Isso era mais de seis horas da tarde. Acharam graça! E olhe a minha consciência, eu pensava que era o pessoal que estava pescando, porque sempre o pessoal fica lá na beira, mas nesse dia não estava pescando era ninguém, e nem era hora de ninguém pescar. Eu não estava nem pensando maldade nenhuma e nem 
medo. No outro dia eu perguntei: Loro, tu estava ontem umas cinco e meia pras seis horas lá no mato ajeitando tua cerca? E ele disse que não. Eu disse: olhe, estavam achando graça lá. E ele disse: eu já vi isso aí. Uma vez fez eu dá com a proa da canoa num pau, que quase eu caí na água com medo.

Neto de Seu Jorge: Eles ficavam conversando perto. Eles ficavam conversando e a gente escuta eles. Égua! E eu achei impressionante. Pesquisadora: o que vocês escutam? Neto de Seu Jorge: Eles conversando, mas a gente não compreende nada. Eles ficam falando rápido. É no igarapé da Flecheira. Eles roçam e a gente não vê nada. Parece quem está cortando uma coisa assim em cima.

Pesquisadora: Aí foste acreditar no teu avô, né?

Neto de Seu Jorge: Agora eu acredito! Seu Jorge: Eu não tenho medo. Nesse igarapé tem coisa, mas não me dá medo.

É possível observar que, com o passar do tempo, as narrativas tendem a se interpenetrar, enriquecendo-se e sofrendo, assim, redefinições, com base em repetições, cancelamentos, esquecimentos e substituições de elementos diversos, consolidando, deste modo, um incessante movimento de interações, que contribui para enriquecer as memórias locais acerca de certos episódios ou situações vividas pelas pessoas.

O Brasil ainda é um país de prevalência vocal, e mesmo nas grandes metrópoles, onde se presume a inexistência das ditas "narrativas tradicionais", elas continuam a fluir com o mesmo caráter de mistério que as animam desde longa data. De acordo com Fares (2005), nas comunidades narrativas tradicionais da Amazônia, conta-se nos cantos, nas portas, nas calçadas, nos bancos, e quanto mais se adentra as matas, ou se abeira os rios, mais o repertório se enriquece e avoluma. Como observa a autora, os narradores orais são pessoas mais experientes, em geral, mais velhas, mas mesmos os jovens, que, muitas vezes, negam esse tipo de conhecimento, por pleitearem experiências "modernas" trazidas pelos meios de comunicação de massa, não se afastam desta rede de signos que representa a tradição ${ }^{17}$ (Fares 2005:6).

A paisagem que rodeia a ilha tem passado pelas modificações que o tempo e as atividades humanas e não humanas lhe imprimem. O cenário de fundo são as abruptas transformações urbanísticas que vêm acontecendo na ilha, alvo da expansão urbana belenense, e as inquietações que despertam nos ilhéus com os visitantes da ilha, nas relações entre a memória, a paisagem e a materialidade (Rodríguez Cácere 2017). Essa concepção de paisagem não se refere exatamente ao "ambiente". Antes, "paisagem" diria respeito à forma assumida pelo ambiente enquanto interação entre organismos, cuja forma específica deriva de um engajamento (Ingold 2000).

17 Tais reflexões se aproximam às considerações de Ecléa Bosi (1994:417), quando a autora afirma o seguinte: "Quando as marés de nossa memória já roeram as vigas, o fato deriva ao sabor das correntezas. No entanto, sofremos no dia a dia a inexorável divisão que nos constrange a deixar a casa pelo trabalho, a juventude pela maturidade e nos rouba do convívio mais caro. É a força do tempo marcado por pontos de orientação que transcende nossa vontade e nos fazem ceder à convenção". 


\subsection{COMUNIDADE NARRATIVA: O MERGULHO NA MEMÓRIA}

Segundo Jacques Le Goff (1996), a memória é a propriedade de conservar certas informações, tratando-se de uma propriedade que se refere ao conjunto de funções psíquicas que permite ao indivíduo atualizar impressões ou informações passadas, ou reinterpretadas como passadas (Le Goff 1996:419). Desse modo, o narrador de histórias nem sempre guarda na memória tudo o que lhe penetra pelos sentidos; na verdade, tudo é captado parcialmente, alguns retalhos ficam, outros se perdem no grande emaranhado que compõe a colcha cultural, na qual ela está envolvida, mas que ele criativamente ordena sob a forma de uma narrativa que apresenta certo tom pessoal.

Diante das narrativas que circulam entre um coletivo, é possível perceber a atenção especial ao ato da escuta. Mais do que falar, há necessidade de ouvir o outro, uma abertura ao diálogo que coloca a escuta como central. Assim, por vezes, os narradores se deleitavam em horas de narrativas, mas sempre as pausas eram longas também, momentos onde o convívio e as conversas mais informais aconteciam.

Neste sentido, o tempo da prosa e o consequente exercício da escuta emergem enquanto uma das formas de sociabilidade mais presentes na experiência vivida por coletivos e, sendo assim, "o que se vê é uma forma cabocla de experienciar o tempo" (Silveira 2004:305). O cotidiano é vivido enquanto algo que se configura numa relação com os lugares compartilhados com o grupo, como formas sutis de experimentar as temporalidades numa duração ${ }^{18}$, numa vontade de perdurar no espaço e no tempo insular. Dona Zilda relaciona o tempo de viver na ilha com as itinerâncias pela metrópole, neste caso, o bairro de Icoaraci às transformações nas paisagens das ilhas, como segue:

Pois é, a gente sempre viveu bem aqui. Quando morava em Icoaraci sentia falta daqui, já tô acostumada, aqui é meu canto. Meus filhos não, só vem agora a passeio, me visitar. Eu não gosto do barulho de carro. Aqui, graças a Deus, ainda não tem carro. Agora o inferno são essas motos que inventaram pra cá [risos]. Eu gosto mesmo de andar de casco. Nunca andei nesse naviozão da prefeitura. Vou pra Icoaraci de popopô mesmo. Vou só pegando ventinho.

O movimento maior mesmo é nas férias, que dá muita gente na praia. Eu gosto de caminhar, só quando preciso ir no Vai quem Quer que pego um bondinho desses, ou charrete. Naquela época, a gente não tinha muita coisa porque não tinha luz. Agora que tem o pessoal passa o dia com som e televisão ligada. Eu, eh! Eu sou da tranquilidade. O pessoal diz que eu sou uma velha chata porque reclamo do barulho, eu sei que falam de mim. Mas o barulho mesmo fica lá pra praia, pra lá tem os bar, as pousadas. Lá que o pessoal vai pra se divertir (Dona Zilda, comunicação pessoal, 2016).

Seguindo os caminhos da memória, de acordo com Fares (2015:34), no momento de narração a

18 Ver Rocha e Eckert (2005). 
memória se enlaça ao esquecimento, pois são "duas forças que se completam, pares indissociáveis". A dupla, memória e esquecimento, em suas oposições complementares dão asas à criação e à recriação, pois "essas oposições são instrumentos conjuntos e indissociáveis em projetos narrativos [...] em que lembrar é um fluxo, um processo, uma razão de ser o ato de esquecer se faz o pivô daquilo que se desenvolverá”. (Ferreira 1995 apud Fares 2015:33-34).

No jogo tensional de lembrar e de esquecer, os narradores lidam com certas vicissitudes espaçotemporais, a partir das quais os eventos narrativos foram (re)tecidos como histórias sobre a ilha. Seu Dimas traz à tona o dilema a partir de episódios já mencionados por nós neste artigo, mas que aqui tomam outras feições diante da questão colocada, como segue:

Era muito difícil o preso conseguir fugir
daqui, e olha que muitos tentavam,
quando conseguia o condenado não
conseguia nadar tanto pra chegar
numa ilha perto. Não! E muitos
morriam afogado, ou virava comida
de peixe grande, na certa. Muita gente
sabe dessa história, do presídio daqui.
Mas também é uma história que muitos
já esqueceu. A gente que mora aqui
é que não esquece, né? (Seu Dimas,
comunicação pessoal, 2017).

Nos estudos de Jerusa Pires Ferreira (1995), a ação da memória se processa de acordo com sistemas internos de cada narrador, portanto, nela ficará registrado somente aquilo que tiver algum significado para ele, algo que lhe desperte a curiosidade e que tenha íntima relação com sua história de vida, que lhe cause indignação ou esteja reforçando suas concepções (Ferreira 1995:127).

A partir das ideias de memória individual e coletiva, chega-se à discussão proposta por Halbwachs (2003), de que a memória individual existe sempre a partir de uma memória coletiva, posto que todas as lembranças são constituídas no interior de um grupo (Halbwachs 2003:30). A memória individual e a memória coletiva constituem-se como importantes fontes das poéticas orais. Convém lembrar que nos estudos de Maurice Halbwachs (2003), a memória não é só um fenômeno de interiorização individual, ela é também, e sobretudo, uma construção social e um fenômeno coletivo. Sendo uma construção social, a memória é, em parte, modelada pelos grupos sociais (Halbwachs 2003:39).

O processo da memória nos estudos de Bosi (1995), por sua vez, chama a atenção para as lembranças das pessoas idosas. Identifica-se, assim, uma história social acentuada nos quadros de referência familiar e cultural igualmente reconhecíveis. Portanto, as memórias das pessoas idosas se encontram ocupadas atentamente pelo próprio passado, ou, ainda, por substâncias mesmas das suas vidas.

Os narradores da pesquisa carregam as lembranças de práticas cotidianas que foram 
mais intensas no passado do que são agora, como ponderam. As imagens que evocam das memórias sobre a organização cultural são dimensões das suas experiências de vida na ilha. Desse modo, entre as suas lembranças, é possível compreender momentos da memória coletiva da ilha de Cotijuba.

\section{CONSIDERAÇÕES FINAIS}

Nesse espaço, os tempos convivem "fundidos e confundidos, caóticos e reverberantes nas paisagens humanizadas, seguindo os ritmos da memória do lugar" (Silveira 2004:302). Nesse fluxo, "toda paisagem apresenta-se de início como ordenada na natureza, numa imensa desordem que nos deixa livres para escolhermos o sentindo que preferimos lhe atribuir" (Lévi-Strauss 2000:54 apud Silveira 2004). A desordem emana no conflito da complexidade da abordagem descritivo-analítica sobre as narrativas, por meio das memórias locais.

Trata-se de expressões do vivido que são próprias às maneiras de ser no tempo e de se alinhar ao espaço. A narrativas sobre a ilha de Cotijuba se recriam porque os devaneios humanos do repouso e da vontade modificam a paisagem de acordo com suas intencionalidades e projeções no espaço habitado (Bachelard 1996).

As narrativas dos antigos moradores emergiram entrelaçadas entre o cotidiano da paisagem e os seres fantásticos das narrativas, também habitantes da ilha, aportados ao imaginário. Esses encontros nos foram dados em espaços de troca de experiências, nas quais, como aponta Ricoeur (1994), a produção de sentido do ato de narrar é percebida na energia criadora presente no discurso. Assim, o encontro com os narradores nos proporcionou momentos de imersão, onde pudemos tecer uma escuta sensível, de aproximação em relação ao objeto de estudo, afirmando o fortalecimento do desejo de conhecê-lo.

Aportamos nas narrativas sobre a ilha repletas de significâncias e significados, as quais possuem vozes, cheiros, cores, sabores. E, por meio disso, "nadamos" nas memórias compartilhadas dos ilhéus, encontrando ressonâncias no que diz Bachelard (1997:97), já que "é o poder de devanear que nos leva para o encontro com o mundo dos sonhos".

\section{AGRADECIMENTOS}

Agradecemos aos pareceristas os ajustes que acreditamos serem justos com a nossa proposta neste artigo. Este artigo é um excerto da dissertação de mestrado da primeira autora e, como tal, é uma abertura ao que virá, já que entendemos que um trabalho de doutorado possibilitará maiores aprofundamentos ao tema proposto. 


\section{REFERÊNCIAS}

Bachelard, G. 1988. A poética do espaço. São Paulo: Martins Fontes.

Bachelard, G. 1996. A poética do devaneio. Trad. Antônio de Pádua Danesi. São Paulo: Martin Fontes.

Bachelard, G. 1997. A água e os sonhos: ensaio sobre a imaginação da matéria. Trad. Antônio de Pádua Danesi. 1. ed. São Paulo: Martins Fontes.

Benjamim, W. 1994. O narrador. Considerações sobre a obra de Nikolai Leskov, in Obras escolhidas, 6. ed. São Paulo: Brasiliense.

Bosi, E. 1995. Memória e sociedade: lembranças dos velhos. 3. ed. São Paulo: Companhia das Letras.

Cascudo, L. C. 1995. Jangada: uma pesquisa etnografia. São Paulo: Global.

Certeau, M. 1994. A invenção do cotidiano: as artes do fazer. Petrópolis: Vozes.

Diegues, A. C. 1998. Ilhas e mares: simbolismo e imaginário. São Paulo: Hucitec.

Durand, G. 1989. As estruturas antropológicas do imaginário. São Paulo: Martins Fontes.

Eckert, C., e A. L. C. Rocha. 2000. O tempo e a cidade. Porto Alegre: Editora da UFRGS.

Eckert, C. 2009. As variações paisageiras na cidade e os jogos da memória, in Paisagem e cultura: dinâmica do patrimônio e da memória na atualidade. Organizado por F. Silveira e C. Cancela. Belém: EDUFPA.

Fares, J. A. 2005. Memória de Belém em história de velhos: aspectos metodológicos. Contadores e Repertórios orais. UEPA. Anais do XXIII Simpósio Nacional de História do ANPUH. 
Fares, J. A. 2015. Um memorial das matintas amazônicas. Belém: Fundação Cultural do Estado do Pará.

Ferreira, J. P. 1995. De magia, tempo e memória, in Imaginário/Memória, pp. 45-67. São Paulo: HUCITEC/EDUC.

Figueiredo, S. L., e A. P. Tavares. 2006. Mestres da cultura. Belém: EDUFPA.

Halbwachs, M. 2003. A memória coletiva. Trad. Beatriz Sidou. São Paulo: Centauro.

Harrison, R. 1992. Forêst: essai sur l'imaginaire occidental. Paris: Flammarion.

Holanda, S. B. 1996. Visão do paraíso. 6. ed. São Paulo: Brasiliense.

Ingold, T. 2000. The perception of the environment: essays in livelihood, dwelling and skill. London: Routledge.

Langdon, J. 1999. A fixação da narrativa: do mito para a poética de Literatura Oral. Horizontes Antropológicos 5(12):13-36. DOI: https://doi.org/10.1590/S0104-71831999000300002

Leão, N., C. Alencar, e A. Veríssimo. 2007. Belém sustentável 2007. Belém: IMAZON.

Le Goff, J. 1996. História e memória. Trad. Bernardo Leitão. 4. ed. Campinas: Editora da UNICAMP.

Leroi-Gourhan, A. 1965. O gesto e a palavra: 2: memória e ritmos. Lisboa: Perspectivas.

Lezama Lima, J. 2001. A busca da identidade insular: uma reflexão sobre a fronteira imaginária. Diálogos 2(2):1-14. DOI: https://doi.org/10.15517/DRE.V2I2.6313

Nora, P. 1993. Entre memória e história. A problemática dos lugares. Projeto História 10:7-28. 
Perlin, J. 1992. História das florestas: a importância da madeira no desenvolvimento da civilização. Rio de Janeiro: Imago.

Pollak, M. 1989. Memória, esquecimento e silêncio. Estudos Históricos 2(3):3-15.

Pollak, M. 1992. Memória e identidade social. Estudos Históricos 5(10):200-215.

Ribeiro, O. 1960. As ilhas atlântidas, in Geográficos, vol. III. Lisboa: Fundação Calouste Gulbenkian.

Ricoeur, P. 1994. Tempo e narrativa. Campinas: Papirus.

Ricouer, P. 2007. A memória, a história e o esquecimento. Trad. Alain François. Campinas, São Paulo: Editora da Unicamp.

Rocha, A. C., e C. Eckert. 2005. O tempo e a cidade. Porto Alegre: UFRGS.

Rodríguez Cácere, L. S. 2017. Paisagem, memória e parentesco no quilombo de Vargem Grande. Etnográfica 21(2):269-292.

Schama, S. 1996. Paisagem e memória. São Paulo: Companhia das Letras.

Sansot, P. 1983. Les formes sensibles de la viesociale. Paris: Presses Universitaires de France.

Santos, M. S. 2005. Os conflitos entre natureza e cultura na implementação do Ecomuseu Ilha Grande. História, Ciências, Saúde - Manguinhos 12:381-400.

Saramago, J. 1998. O conto da ilha desconhecida. Ilustrado por aquarelas de Arthur Luiz Piza. São Paulo: Companhia das Letras. 
Silveira, F. L. A. 2004. As paisagens fantásticas e o barroquismo das imagens. Estudo da memória coletiva dos contadores de causos da região missioneira do Rio Grande do Sul. Tese de Doutorado, Universidade Federal do Rio Grande do Sul, Porto Alegre.

Simmel, G. 1979. A metrópole e a vida mental, in O fenômeno urbano. Organizado por O. Velho. Rio de Janeiro: Zahar.

Simmel, G. 1983. A natureza sociológica do conflito, in Simmel. Organizado por E. Moraes Filho, pp. 122-134. São Paulo: Ática.

Siqueira, A. Juraci. 2008. Eu, o Boto. Blog do Boto. Disponível em: http://blogdobotojuraci.blogspot. com/search?q=eu\%2C+o+boto. Acesso em: 11 nov. 2020.

Taussig, M. 1993. Mimesis and alterity. New York: Routledge.

Turner, V. 1996. Dramas, fields and metaphors. Ithaca/London: Cornell University Press.

Yates, F. 2007. A arte da memória. Trad. Flávia Bancher. Campinas: UNICAMP. 